\title{
The Microstructure and Properties of Carbon Thin Films on Nanobainitic Steel
}

\author{
EMILIA SKOŁEK, MONIKA MEREDYK, MICHAŁ TARNOWSKI, \\ TOMASZ BOROWSKI, KRZYSZTOF KULIKOWSKI, RAFAŁ CHODUN, \\ SZYMON MARCINIAK, JERZY ROBERT SOBIECKI, and WIESŁAW ŚWIĄTNICKI
}

\begin{abstract}
The aim of this study was to assess whether it is possible to produce a high adhesive carbon coating by applying low-temperature RFCVD and glow discharge methods on nanobainitic X37CrMoV5-1 steel with and without nitrided sublayer. For this purpose, several methods of investigation were used: observations of coating morphology by scanning electron microscopy (SEM), analysis of bonds found in coatings (Raman spectroscopy), microhardness tests and adhesion of coatings (Scratch tests). Our research has shown that low-temperature RFCVD and glow discharge processes of nanobainitic X37CrMoV5-1 steel allow producing carbon coatings that can be described as hardened carbon coatings with very high hardness $\rightarrow 2000 \mathrm{HV} 0.25$ in case of RFCVD processes and $>3300 \mathrm{HV} 0.025$ for glow discharge process and low friction coefficient-near 0.12 at $5 \mathrm{~N}$ load. However, the adhesion of produced coatings to the steel substrate strongly depends on the appropriate selection of the process parameters and on the proper preparation of the substrate before the deposition regarding the thermal stability of nanobainite.
\end{abstract}

https://doi.org/10.1007/s11661-021-06453-9

(c) The Author(s) 2021

\section{INTRODUCTION}

Progress in industrial productions is often strongly related to the development of new highstrength materials. Particular attention is paid to the new generations of steel, which combine high mechanical properties with low production costs. One of the most promising ways to improve the strength and performance of steel components is the use of steels with nanobainitic microstructure. This can be obtained through bainitic transformation. ${ }^{[1-3]}$ Nanobainitic steels are characterized by a good compromise among strength, ductility and fracture toughness compared to steels with conventional tempered martensite microstructure. So far, the nanobainitic microstructure has been obtained in steels with a specially designed chemical composition, with high content of carbon and manganese, ensuring high hardenability and stabilization of residual austenite and an increased amount of silicon, inhibiting the precipitation of cementite during

EMILIA SKOŁEK, MONIKA MEREDYK, MICHAI TARNOWSKI, TOMASZ BOROWSKI, KRZYSZTOF KULIKOWSKI, RAFAE CHODUN, SZYMON MARCINIAK, JERZY ROBERT SOBIECKI, and WIESŁAW ŚWIĄTNICKI are with the Faculty of Materials Science and Engineering, Warsaw University of Technology, Woloska 141, 02-507 Warsaw, Poland. Contact e-mail: emilia.skolek@pw.edu.pl.

Manuscript submitted August 3, 2020; accepted August 30, 2021.

Article published online September 22, 2021 isothermal quenching. ${ }^{[1-4]}$ However, recent studies have shown that in some commercial steel grades, e.g., X37CrMoV5-1 hot working tool steel, a nanobainitic microstructure, which improves the mechanical properties of this steel, can also be produced. ${ }^{[5]}$ Unfortunately, the reduced carbon content in this steel affects the stability of residual austenite. Unstable austenite can undergo martensitic transformation during final cooling after heat treatment or under stress, which increases the hardness of the material and reduces its resilience. Higher martensite content in the microstructure of steel could also improve the wear resistance. However, our own experiments showed that some steels subjected to nanobainitization undergo relatively fast frictional wear under service conditions.

Reduction of wear can be achieved by modifying the surface layer by introducing atoms of certain elements into the material and producing a diffusion surface layer, or, for example, depositing thin coatings of superhard materials, such DLC, $\mathrm{CrN}$ or $\mathrm{BN}$, on the surface.

When selecting the appropriate method of coating deposition on a nanocrystalline substrate, it should be remembered that the nanocrystalline structure, similar to martensite, is thermodynamically metastable; thus, the processing temperature should not exceed the temperature of thermal stability of the nanobainitic microstructure, which is relatively low. ${ }^{[5]}$ Due to this limitation, only low-temperature techniques, e.g., glow 
discharge processes, PACVD or PAPVD, are useful to modify the surface. Processes of low-temperature deposition of carbon coatings, e.g., DLC coatings, meet the temperature criterion.

Diamond-like carbon (DLC) is an amorphous material with carbon atoms bonded in the $\mathrm{sp}^{3}$ and $\mathrm{sp}^{2}$ hybridization. ${ }^{[6]} \mathrm{Sp}^{3}$ binding in DLC gives many attractive physical and mechanical properties, such as high hardness, chemical and electrochemical inertness, and band gap width, which make DLC coating properties similar to those of diamonds. ${ }^{[7,8]}$ In addition, the friction coefficient of DLC coatings is inversely proportional to their hardness, so the harder the coating, the slower its wear. ${ }^{[7,8]}$ Because the DLC coating process is much cheaper than that of diamond coating, DCL is more popular and widely used. ${ }^{[8]}$ Since the processes of DLC deposition, such as IBD, IBAD, PECVD and PLD ${ }^{[8-13]}$ are low-temperature processes, DLC coatings can be produced on plastics or other materials that are not resistant to high temperatures. ${ }^{[14]}$ However, due to high hardness and high internal stresses, this type of coating is characterized by low adhesion to the substrate. This problem can be overcome by producing layers composed of elements such as nitrogen, silicon, titanium or tungsten on the substrate transition (buffer).$^{[15-17]}$ The production of an intermediate layer is very important, because it allows depositing a coating with the desired adhesion and also enables the transfer of stress in the case of mechanical loads present during frictional wear. ${ }^{[18,19]}$

To date, there are very few reports in the literature regarding the surface engineering of nanobainitic steels due to many limitations of surface engineering related to the thermal stability of nanocrystalline microstructures. Attempts to combine nanobainitization with surface engineering treatments were focused mainly on nanobainitization of carburized low-carbon steels ${ }^{[20-22]}$ or nitrocarburizing of specially designed nanobainitic steel. ${ }^{[23]}$ Therefore, it is crucial to investigate whether it is possible to produce a high adhesive carbon coating by applying low-temperature RFCVD and glow discharge $\mathrm{p}$ on commercial X37CrMoV5-1 steel after nanostructurization, with and without a nitrided sublayer, at a temperature lower than the thermal stability of the nanocrystalline microstructure. An additional goal was to check how the sublayer influences the adhesion and properties of the top layer.

\section{MATERIALS AND METHODOLOGY}

Samples made of nanobainitic X37CrMoV5-1 steel with the chemical composition presented in Table I, microstructure shown in Figure 1 and mechanical properties listed in Table II were subjected to various surface engineering treatments: low-temperature carbon coating production in glow discharge conditions and RFCVD method. To analyze the influence of the nitrided layer on the adhesion and properties of carbon coatings, some samples were subjected to low-temperature glow discharge nitriding before the deposition processes. Details of the austempering heat treatment that allowed obtaining a nanobainitic microstructure, the microstructure itself and mechanical properties of $\mathrm{X} 37 \mathrm{CrMoV5}-1$ nanobainitic steel are described elsewhere. ${ }^{[5,24,25]}$

Two variants of low-temperature glow discharge carbon coating production were carried out. The first was a single low-temperature carbon coating production in glow discharge conditions at $400{ }^{\circ} \mathrm{C}$ for 20 minutes in a mixture of $\mathrm{CH}_{4}$ and $\mathrm{N}_{2}$ (GDCC). The second was a continuous process consisting of low-temperature glow discharge nitriding at $400{ }^{\circ} \mathrm{C}$ for 6 hours in $\mathrm{N}_{2}$ atmosphere followed by carbon coating production in glow discharge conditions at $400{ }^{\circ} \mathrm{C}$ for 20 minutes in a mixture of $\mathrm{CH}_{4}$ and $\mathrm{N}_{2}$ (NGDCC).

Before the RFCVD process, all nanobainitic steel samples were subjected to low-temperature glow discharge nitriding (LTN) at $420{ }^{\circ} \mathrm{C}$ for 6 hours. Samples with nitrided layers were subjected to two different RFCVD processes in $\mathrm{CH}_{4} / \mathrm{N}_{2}$ atmosphere for $30 \mathrm{~min}$. In the first process (RFCVD1), the current-voltage parameters were changing during the process to ensure optimal synthesis conditions. In the second (RFCVD2), constant parameters were assumed. In both processes, the temperature of the coating did not exceed $50{ }^{\circ} \mathrm{C}$. After completion of the processes, samples were left in the chamber for 24 hours to stabilize the produced coatings.

All surface-treated samples were subjected to macroand microscopic observations. The produced coatings were observed on the surface and cross section using SEM. The surface roughness of the coatings was analyzed using a Veeco WYKO NT9300 optical profilometer carrying out three measurements for each sample. $R_{\mathrm{a}}$ and $R_{\mathrm{q}}$ parameters were determined using the Vision program $\left(R_{\mathrm{a}}\right.$ is the arithmetic average of the absolute values of the profile heights over the evaluation length; $R_{\mathrm{q}}$ is the root mean square average of the profile heights over the evaluation length). The number of $\mathrm{sp}^{3}$ bonds was determined using Raman spectroscopy. The Raman scattering used $2.33 \mathrm{eV}$ (532 nm VIS laser) and $4.66 \mathrm{eV}$ (266 nm UV laser). As the source of $532 \mathrm{~nm}$ excitation, an $\mathrm{Ar}+$ laser was used. During the measurements, the laser beams were focused onto $20-\mu \mathrm{m}$ spots. The parameters of spectra registration were optimized based on the satisfactory intensity of the peaks. $\mathrm{Sp}^{3}$ bond content was evaluated basing on $\mathrm{G}$ peak parameters: G peak FWHM and G peak dispersion rate. ${ }^{[26-28]}$ After the spectra registration, no surface damage of samples was detected.

Microhardness of sample surfaces was measured under two load values: $25 \mathrm{G}$ and $50 \mathrm{G}$, in accordance with PN-EN ISO 6507-1 standard. ${ }^{[29]}$ Obtained results were compared to the hardness of nanobainitic X37CrMoV5-1 steel without surface treatment and after low-temperature glow discharge nitriding (LTN). In case of LTN + RFCVD2 treatment, hardness measurements were carried out on the middle and edge of the sample. Nanohardness measurements were carried out using MicroMaterials Nanotest Vantage equipment. Maximum load of $2 \mathrm{mN}$, loading time of 20 seconds, dwell period of 10 and 20 seconds unloading time were applied. For every sample, 100 indentations were performed, and mean values were calculated. Adhesion 
Table I. Chemical Composition of X37CrMoV5-1 Steel (Weight Percent)

\begin{tabular}{ccccccccc}
\hline & C, Percent & Si, Percent & Mn, Percent & Cr, Percent & Mo, Percent & V, Percent & Ni, Percent & Fe, Percent \\
\hline X37CrMoV5-1 & 0.37 & 1.01 & 0.38 & 4.91 & 1.2 & 0.34 & 0.19 & Balance \\
\hline
\end{tabular}

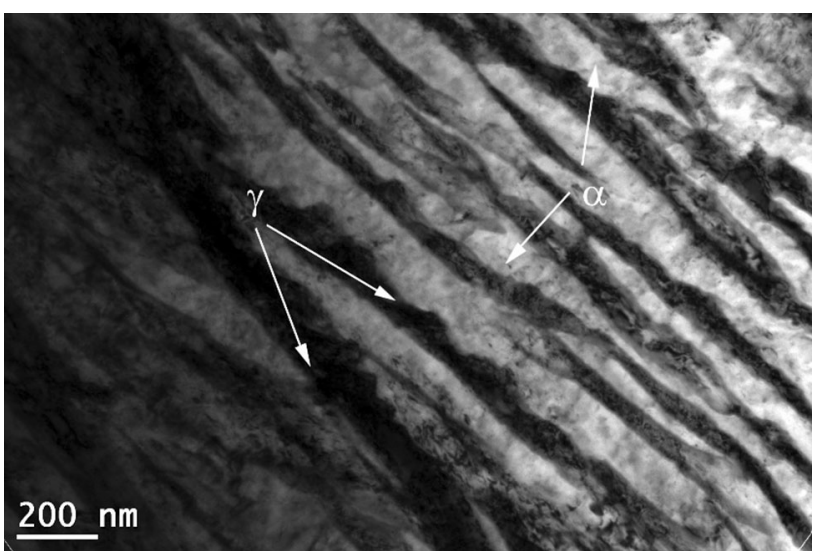

Fig. 1-Microstructure of nanobainitic X37CrMoV5-1 steel.

Table II. Mechanical Properties of Nanobainitic X37CrMoV5-1 Steel

\begin{tabular}{lccc}
\hline$R_{0.2}, \mathrm{MPa}$ & $R_{\mathrm{m}}, \mathrm{MPa}$ & $A_{\mathrm{T}}$, Percent & $A_{\mathrm{u}}$, Percent \\
\hline $734 \pm 8$ & $1763 \pm 55$ & $16.6 \pm 1.4$ & $12.1 \pm 0.6$ \\
\hline
\end{tabular}

Table III. Parameters of the Scratch Test

\begin{tabular}{ll}
\hline Initial Load & \multicolumn{1}{c}{$1 \mathrm{~N}$} \\
\hline Final load & $50 \mathrm{~N}$ \\
Scratch length & $5 \mathrm{~mm}$ \\
Load indicator & $10 \mathrm{~N} / \mathrm{min}$ \\
Feed speed & $1.02 \mathrm{~mm} / \mathrm{min}$ \\
\hline
\end{tabular}

of the coatings to the substrate was analyzed using a scratch tester with a Rockwell diamond indenter with $200 \mu$ m diameter. ${ }^{[30]}$ Scratches were observed using LM and SEM. Detailed parameters of the scratch test are presented in Table III. The scratch test also allowed measuring the friction coefficient of the produced coatings.

\section{RESULTS}

Carbon coating produced in glow discharge conditions (GDCC) on the surface of nanobainitic steel did not show any adhesion to the nanobainitic substrate and dropped off immediately (Figure 2(a)). Poor adhesion of hard coatings to the surface is a very common phenomenon, associated with high internal stresses. ${ }^{[14}$ To increase the hardness of the substrate and reduce the (a)

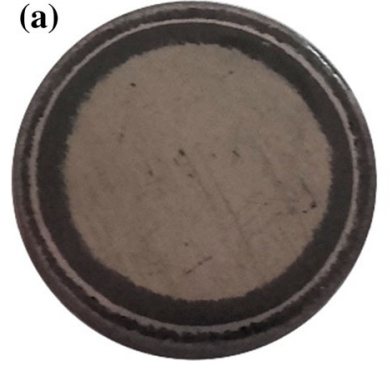

(b)

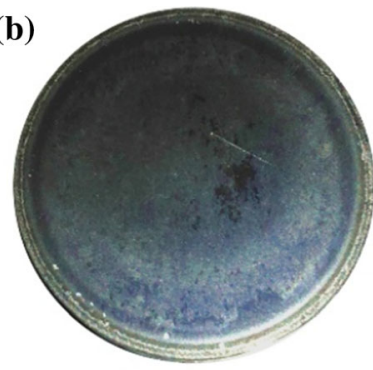

Fig. 2-Morphology of carbon coating produced on a surface of nanobainitic steel by glow discharge carbon coating in glow discharge conditions (GDCC) (a) and continuous process of low-temperature glow discharge nitriding followed by carbon coating production in glow discharge conditions (NGDCC) (b).

(a)
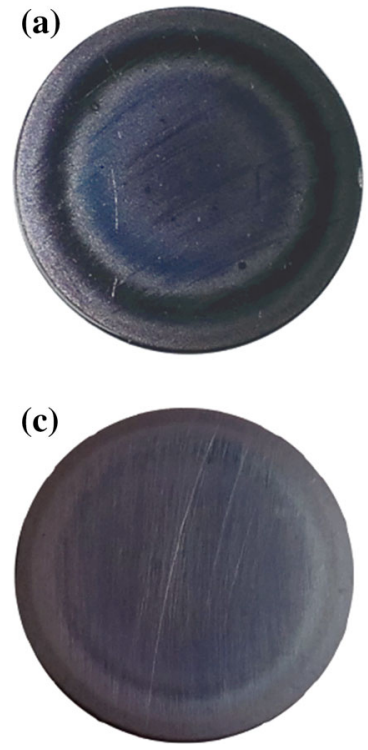

(b)

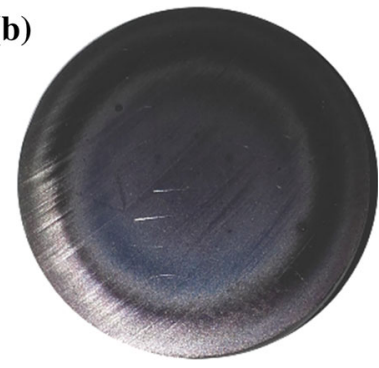

(d)

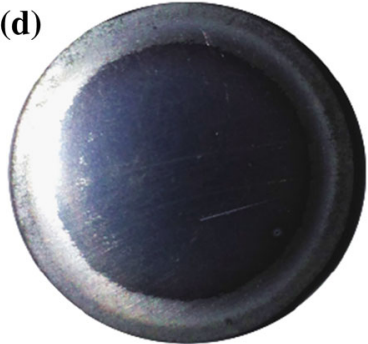

Fig. 3-Morphology of carbon coating produced on nitrided (LTN) surface of nanobainitic steel by RFCVD1: $(a)$ directly after deposition, (b) a few months after deposition; RFCVD2: (c) directly after deposition, $(d)$ a few months after deposition.

residual stresses, an additional process was carried out before the carbon coating formation. It consisted of low-temperature glow discharge nitriding in glow discharge conditions (NGDCC). This process led to a dark coating with a good adhesion to the substrate. Even after a few months, the coating was still present on the surface (Figure 2(b)). Another two-step process, consisting of glow discharge low-temperature nitriding (LTN) and RFCVD1, with adjustment parameters, also produced a dark permanent layer (Figures 3(a) and (b)). 
In case of LTN and RFCVD2 with constant process parameters, some defects of the coating on the edge of the sample were revealed a few weeks after deposition (Figures 3(c) and (d)).

The glow discharge process (NGDCC) led to a very smooth surface of the layer, with some pores distributed randomly on the surface (Figure 4(a)). The layer had about $2 \mu \mathrm{m}$ thickness and was clearly separated from the substrate (Figure 4(b)). Since the process was carried out at a temperature $<400{ }^{\circ} \mathrm{C}$, the structural changes should not have occurred in the sample core. ${ }^{[5]}$ After LTN and RFCVD1 with adjustment parameters, there were many very fine grains on the surface (Figure 5(a)), and the thickness of the layer was smaller by about $0.5 \mu \mathrm{m}$. The morphology of the layer after LTN and RFCVD2 was similar to that produced during the RFCVD1 process; however, the number of fine grains was higher and their distribution more uniform (Figure 6(a)). Also, in this case the layer was very thin, about $0.5 \mu \mathrm{m}$ (Figure 6(b)).

A clear increase in roughness (Table IV) was observed for coatings after the RFCVD2 process, caused by a large number of fine grains (Figure 6(a)). The $R_{\mathrm{a}}$ and $R_{\mathrm{q}}$ parameters for the RFCVD1 coating were the lowest compared to other coatings because of the lowest number of fine grains present on the surface of this coating (Figure 5(a)). On other hand, NGDCC coating shows intermediate surface roughness values, higher than RFCVD1 coating and lower than RFCVD2. It is worth noting that small pores present after NGDCC process (Figure 4(a)) influence the roughness of this coating (Table IV).

The typical Raman spectrum of DLC coating consisted of two peaks: D and G. Peak D appears at about $1350 \mathrm{~cm}^{-1}$ and corresponds to the disordered graphitic structure. Peak $G$ appears at about $1580 \mathrm{~cm}^{-1}$ and is characteristic of stretching vibrations of $\mathrm{sp}^{2}$ atoms. Position, intensity and width of Raman spectra are correlated to the density, size and structure of clusters of $\mathrm{sp}^{2}$ bonds and depend on the number of $\mathrm{sp}^{3}$ bonds. ${ }^{[26]}$ $\mathrm{Sp}^{3}$ bond content was evaluated based on $\mathrm{G}$ peak parameters - G peak FWHM and G peak dispersion rate-since it is the easiest peak to determine in the Raman spectrum of amorphous carbon films during the fitting operation. ${ }^{[31]}$ From these methods, the smallest error during the fit was predicted.

Fitting, carried out for the experimental Raman spectra, allowed determining the position, FWHM and intensity of both peaks: D and G. Measured spectra and fitted elementary components are shown in Figure 7. The position of the $G$ peak varies slightly, depending on the treatment, from 1596 to $1601 \mathrm{~cm}^{-1}$ for the $266 \mathrm{~nm}$ laser beam and 1575 to $1582 \mathrm{~cm}^{-1}$ for the $532 \mathrm{~nm}$ laser beam (Table IV). Shifting of the G-peak position towards lower values indicates an increasing share of $\mathrm{sp}^{3}$ bonds and a decrease in the share of $\mathrm{sp}^{2}$ bonds; thus, it can be assumed that the highest amount of sp3 bonds occurs after LTN + RFCVD1 treatment. The highest value of FWHM for this sample suggests its highest amorphization and disorder of the structure (bond lengths and bond angles). At the same time, a relatively high ratio of $I_{\mathrm{D}} / I_{\mathrm{G}}$ compared to other samples indicates a larger amount and size of $\mathrm{sp}^{2}$ clusters in this sample.

Using different excitation wavelengths, the dispersion of peaks can be determined: dispersion occurs when there is a peak shift in a function of excitation energy. This phenomenon is related to the disorder of the structure. ${ }^{[27,28]}$ For the $\mathrm{G}$ peak, its dispersion is related to the participation of $\mathrm{sp}^{2}$ carbon atoms in aromatic rings in respect to atoms in olefin chains. ${ }^{[26]}$ The small degree of dispersion of the $G$ peak corresponds to a small content of $\mathrm{sp}^{2}$ atoms in the chains and thus indicates the nanocrystalline-amorphous form of carbon (Tables IV, V). Similar conclusions can be drawn from estimation of the content of $\mathrm{sp}^{3}$ bonds based on the mutual intensity of D and G peaks, ${ }^{[27]} \mathrm{FWHM}^{[32]}$ half width and $G$ peak position. ${ }^{[28]}$ The obtained results indicate that none of the performed surface treatments allowed producing typical DLC coatings in which the content of $\mathrm{sp}^{3}$ bonds was close to or even higher than 50 pct. Nevertheless, produced coatings can be described as hardened carbon coatings, an intermediate state between nc-G and a-C, ${ }^{[33]}$ which should significantly increase the hardness of the surface of nanocrystalline steel.

All produced coatings are characterized by very high hardness (Figure 8), significantly higher compared to nanobainitic X37CrMoV5-1 steel without coating and
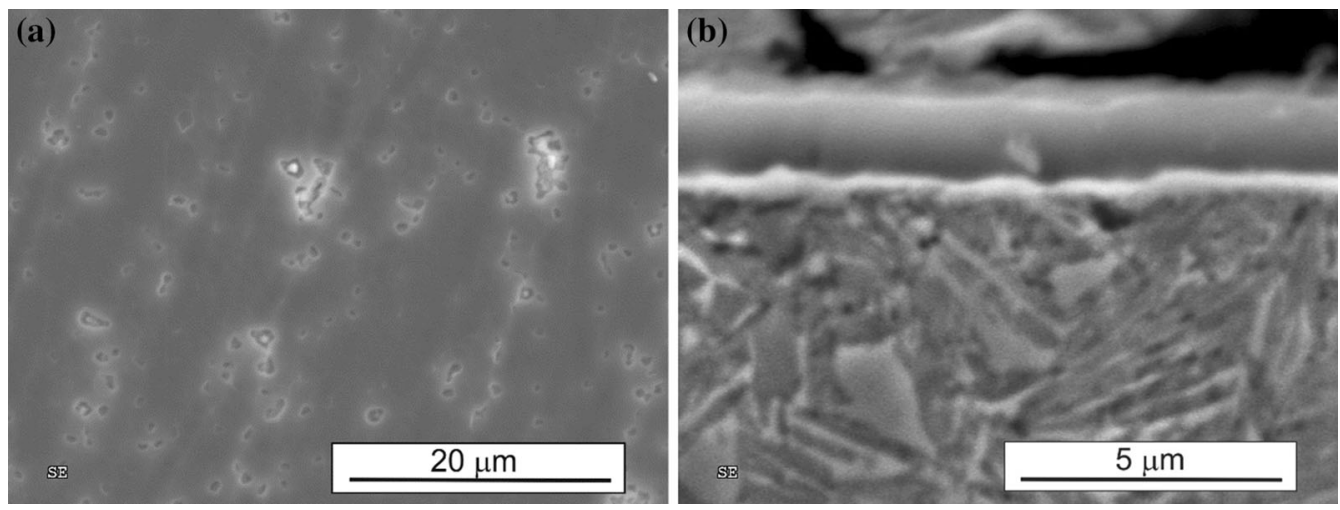

Fig. 4-Microstructure of the surface $(a)$ and on the cross section $(b)$ of carbon coating produced on a surface of nanobainitic steel in a continuous process of low-temperature glow discharge nitriding followed by carbon coating produced in glow discharge conditions (NGDCC). 

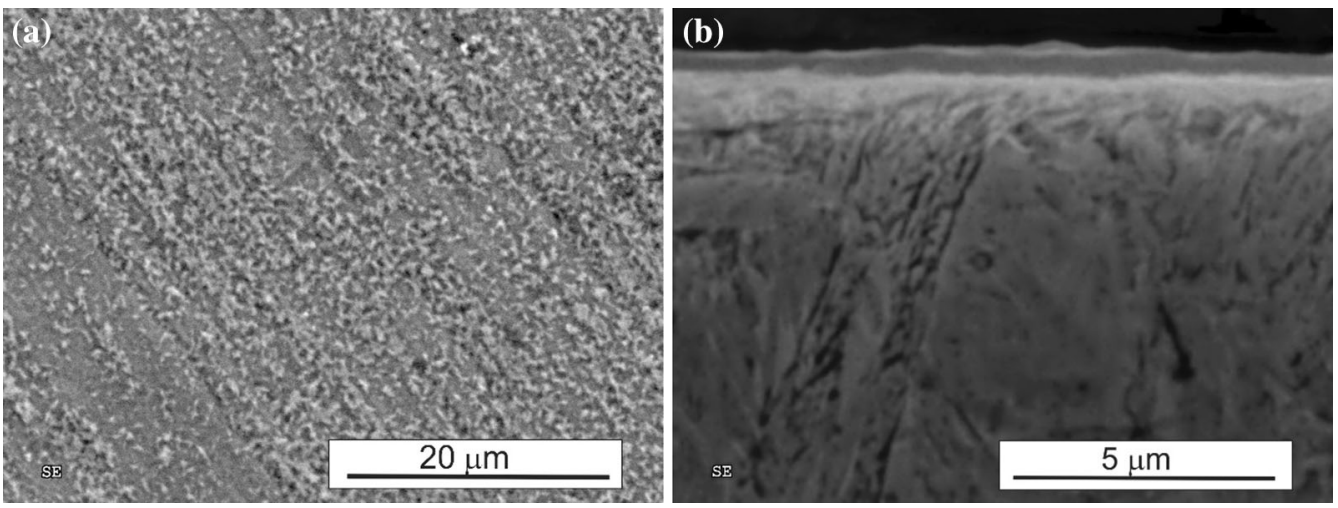

Fig. 5-Microstructure of the surface $(a)$ and on the cross section $(b)$ of carbon coating produced by RFCVD1 on nitrided (LTN) layer of a surface of nanobainitic steel.
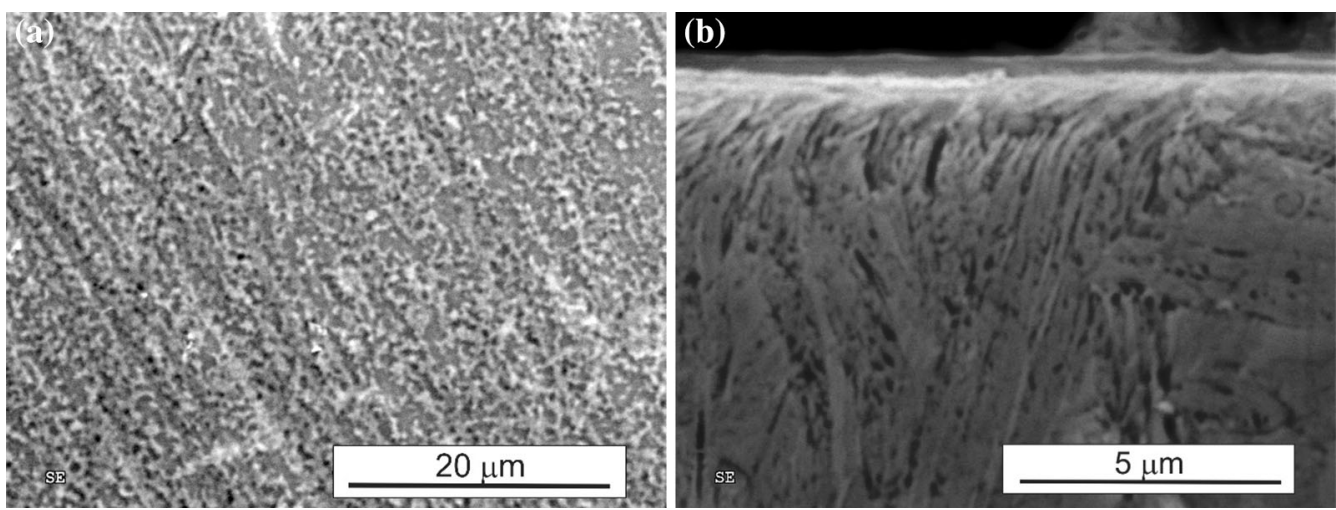

Fig. 6-Microstructure of the surface $(a)$ and on the cross section $(b)$ of carbon coating produced by RFCVD2 on nitrided (LTN) surface of nanobainitic steel.

Table IV. Surface Roughness of Produced Coatings

\begin{tabular}{lcc}
\hline Treatment & $R \mathrm{a}, \mathrm{nm}$ & $R_{\mathrm{q}}, \mathrm{nm}$ \\
\hline NGDCC & 152 & 207 \\
LTN + RFCVD1 & 121 & 164 \\
LTN + RFCVD2 & 234 & 320 \\
\hline
\end{tabular}

nanobainitic X37CrMoV5-1 after the LTN process. The highest hardness was measured for the coating produced during continuous nitriding followed by carbon coating production in a glow discharge condition process (NGDCC). After both RFCVD processes of nitride steel, the hardness value is similar. Due to the very low thickness of these two coatings, it cannot be ruled out that the measurement was influenced by the substrate. During the test, the indenter could break through the coating.

Microhardness measurements show the same correlation between samples as nanoindentation measurement results, which are presented in Tables VI and VII. Highest hardness values (ca. $18 \mathrm{GPa}$ ) were obtained for the NGDCC sample. Both RFCVD coatings are characterized by hardness of ca. $15 \mathrm{GPa}$. These coating are more rigid than those obtained in the NGDCC process (higher reduced Young's modulus). These hardness and
Er values can indicate a hard a-C:H coating containing 30 to 40 pet sp3 bindings. ${ }^{[34,35]}$

Scratch test revealed that the best friction coefficient was obtained for LTN + RFCVD1; the friction coefficient changes gradually and evenly (Figure 9). After the $\mathrm{LTN}+\mathrm{RFCVD} 2$ process, the value of this parameter was slightly higher compared to LTN + RFCVD1, and the curve changed non-uniformly. Some significant changes in friction coefficient value were also observed (Figure 9). Coatings produced during the continuous process (NGDCC) exhibit the highest friction coefficient values with increasing load. In this sample at low and medium loads, friction coefficient values increase evenly with load; however at higher load, about $38 \mathrm{~N}$, a rapid rise of this parameter was observed. However, at low and medium load the friction coefficient of all carbon coatings is still lower than for the nitrided layer. This is probably related to the formation of transfer film between the sample surface and indenter. ${ }^{[36,37]}$

The acoustic emission measured for the sample after continuous process consisting of nitriding followed by carbon coating production in glow discharge conditions (NGDCC) revealed first signal changes, corresponding to the adhesive damage of the coating at $10 \mathrm{~N}$ load. Damages appeared mainly inside and on the edges of the scratch (Figure 10), which was confirmed by SEM observations. The increase of the load to $40 \mathrm{~N}$ caused 

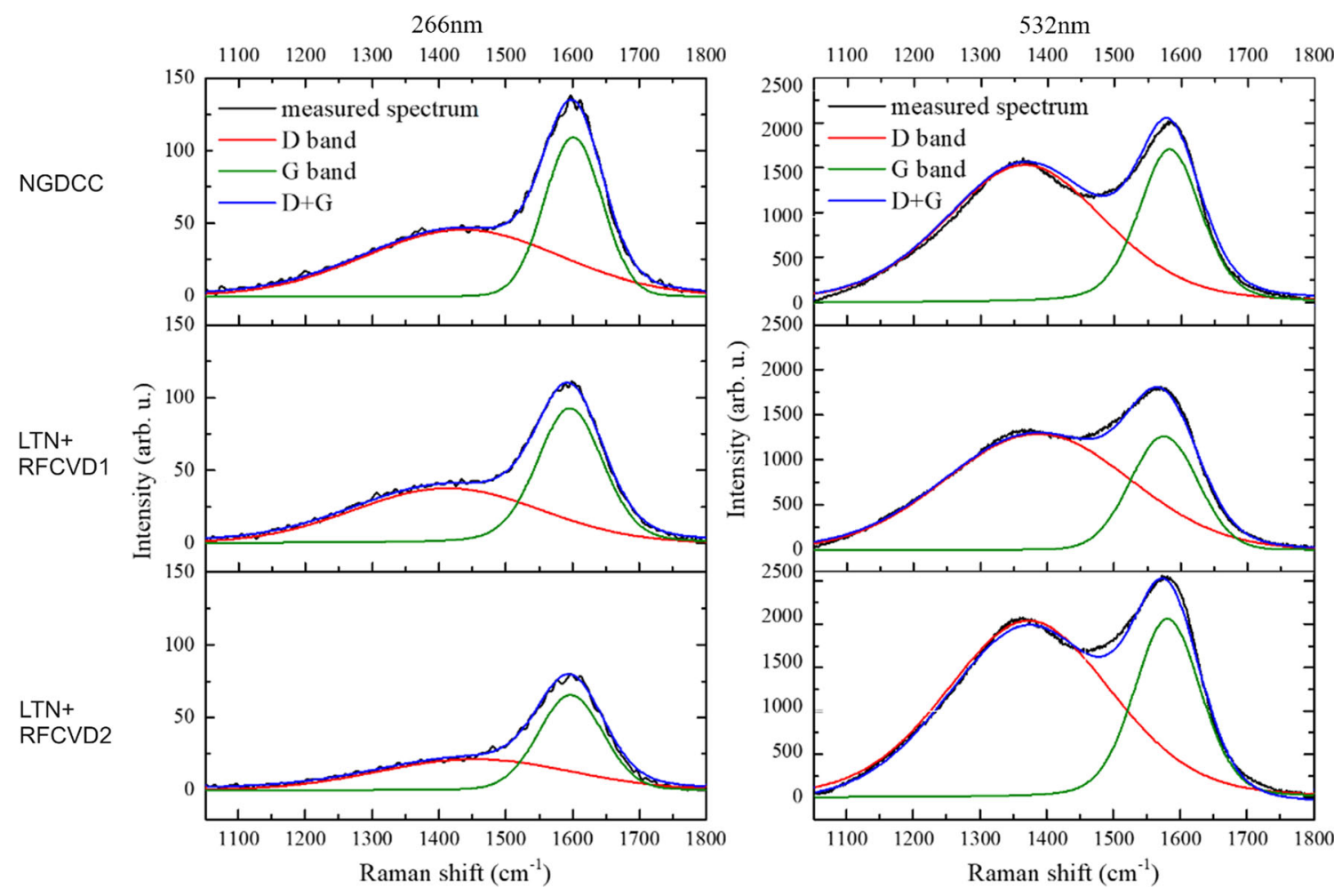

Fig. 7-Raman spectra of carbon films produced by various surface treatments of nanobainitic steel collected under $266 \mathrm{~nm}$ (left column) and $532 \mathrm{~nm}$ (right column) laser beam wavelength excitation.

complete exposure of the soft substrate, which was accompanied by a visible increase of the friction coefficient and a decrease of the acoustic emission. SEM observations revealed partial delamination of the coating in the near scratch zone.

For LTN + RVCVD 1, movement cracks that were small, rounded and perpendicular to the direction of the indenter occurred along the entire length of the scratch. These cracks corresponded to cohesive damage, which did not cause exposure of the substrate. However, they affected the rapid changes of the acoustic emission signal. Small delamination on the inner edges of the scratch appeared at a load of $30 \mathrm{~N}$; their amount increased gradually with increasing force, which was confirmed by SEM observations (Figure 11).

After LTN + RFCVD 2, adhesive damages already appeared over $5 \mathrm{~N}$ of load. This indicated that the adhesion of the layer to the substrate was very low. The rapid change of acoustic emission signal over $20 \mathrm{~N}$ of load is related to strong cracks in the coating under indenter pressing (Figure 12). SEM observations confirmed low adhesion of the coating. On SEM micrographs numerous areas where the coating delaminated and dropped off were observed. The above results indicate that the highest adhesion was obtained during the LTN + RFCVD1 process. Continuous NGDCC process allowed producing a coating with very high hardness, but its friction coefficient and adhesion were the lowest.

\section{DISCUSSION}

The adhesion of thin coatings is conditioned by internal stresses, hardness, and chemical and phase composition of the substrate. ${ }^{[38,39]}$ Hardness of the austempered sample is relatively low compared to the nitrided steel (Figure 8). This is probably the main reason for low adhesion and low durability of the coating without an intermediate layer. Low hardness influences low adhesion of the layer to the substrate. Other authors also observed delamination of a DLC coating deposited on the untreated steel substrate related to the residual stresses in the coating. ${ }^{[40]}$ Glow discharge nitriding process introduces internal stresses and improves hardness of the steel surface ${ }^{[41,42]}$; thus, the adhesion of the coating produced on nitride substrate is higher. By increasing time and temperature of glow discharge nitriding of steel stresses, hardness and thickness in the nitrided intermediate layer grow. ${ }^{[36,42,43]}$ Thus, it can be assumed that the adhesion of thin, hard coatings may also increase. The additional parameters improving the adhesion are a thin, dense and uniform compound layer and mild changes in hardness and stress on the cross section of the layer, smoothly reducing 
Table V. Raman Spectra Parameters: G-Band Position, $I_{\mathrm{D}} / I_{\mathrm{G}}$ Ratio and FWHM of G Peak for 266-nm Laser Beam Wavelength Excitation

\begin{tabular}{|c|c|c|c|c|c|c|}
\hline \multirow[b]{3}{*}{ Treatment } & \multicolumn{6}{|c|}{ Spectrum Parameters } \\
\hline & $I_{\mathrm{D}} / I_{\mathrm{G}}$ & $\mathrm{FWHM}_{\mathrm{G}}, \mathrm{cm}^{-1}$ & $\operatorname{Pos}(\mathrm{G}), \mathrm{cm}^{-1}$ & $I_{\mathrm{D}} / I_{\mathrm{G}}$ & $\mathrm{FWHM}_{\mathrm{G}}, \mathrm{cm}^{-1}$ & $\operatorname{Pos}(\mathrm{G}), \mathrm{cm}^{-1}$ \\
\hline & \multicolumn{3}{|c|}{$266 \mathrm{~nm}$} & \multicolumn{3}{|c|}{$532 \mathrm{~nm}$} \\
\hline NGDCC & 0.41 & 101.349 & 1601.23 & 0.899 & 110.155 & 1582.84 \\
\hline LTN + RFCVD1 & 0.41 & 116.748 & 1596.16 & 1.024 & 119.805 & 1575 \\
\hline $\mathrm{LTN}+\mathrm{RFCVD} 2$ & 0.32 & 113.46 & 1596.87 & 0.99 & 117.36 & 1581.29 \\
\hline
\end{tabular}

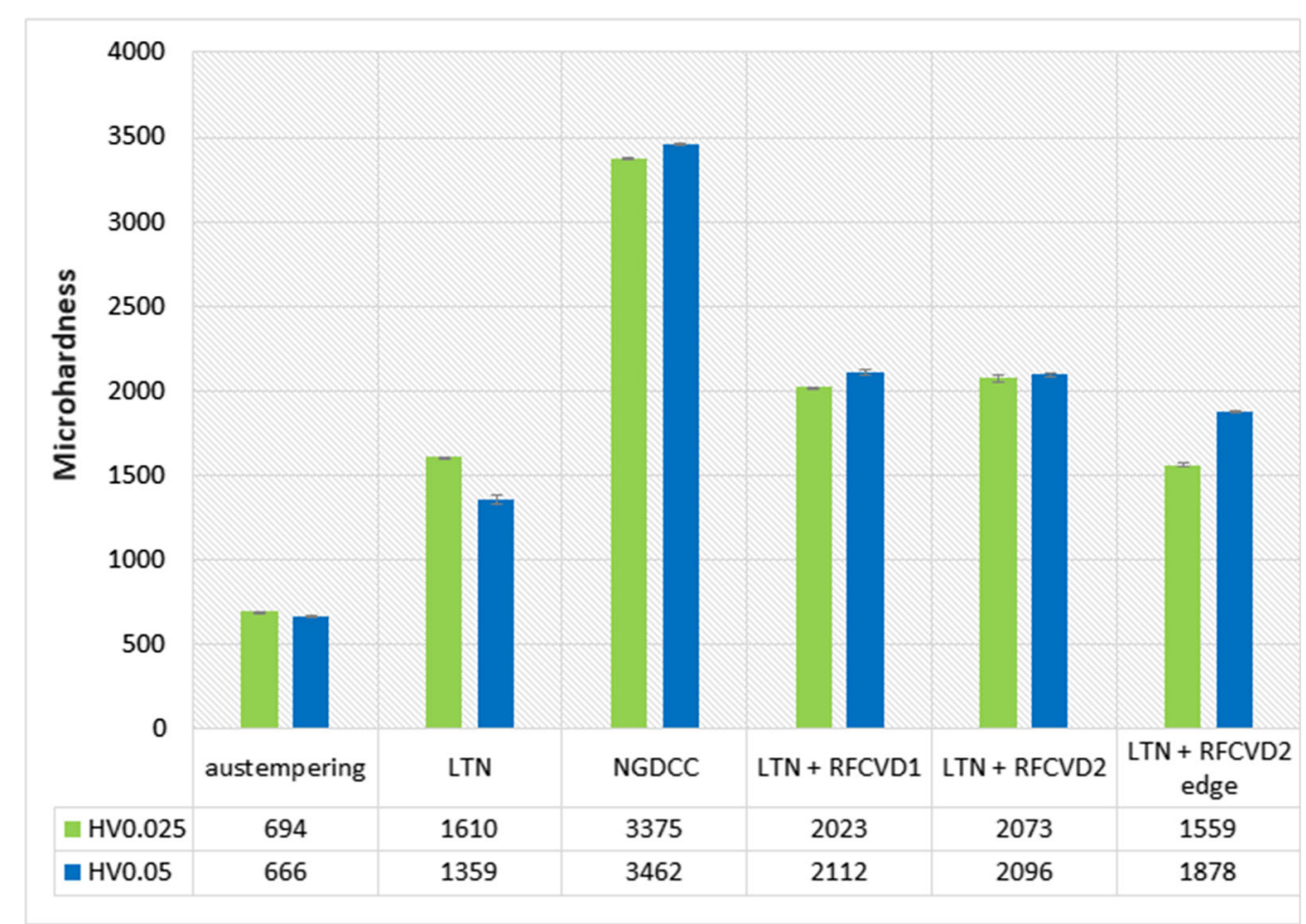

Fig. 8-Microhardness of carbon coatings produced on nitrided nanobainitic steel.

Table VI. Estimated Content of $\mathrm{sp}^{3}$ Bonds in Carbon Films Produced by Various Surface Treatments of Nanobainitic Steel

\begin{tabular}{lccrr}
\hline & \multicolumn{3}{c}{$\mathrm{sp}^{3}$ Estimation Method } \\
\cline { 2 - 5 } Treatment & $I_{\mathrm{D}} / I_{\mathrm{G}}($ Percent $)$ & FWHM $_{\mathrm{G}}$, Percent & Pos(G), Percent & Dis(G), Percent \\
\hline NGDCC & $10-15$ & 5 & 5 & $10.28( \pm 6)$ \\
LTN + RFCVD1 & $10-15$ & 10 & 7 & $12.89( \pm 6)$ \\
LTN + RFCVD2 & $0-10$ & $0-10$ & $0-10$ & $7.64( \pm 6)$ \\
\hline
\end{tabular}

$I_{D} / I_{G}$ : method of estimating sp3 bond content depending on the intensity ratio of peaks D and $\mathrm{G}^{[27]}{ }^{\left[2 W H M_{G}\right.}$ : method of estimating sp3 bond content, depending on the $\mathrm{G}$ peak half-width. ${ }^{[26]} \operatorname{Pos}(G)$ : method of estimating sp3 bond content, depending on the G peak position G. ${ }^{[28]}{ }^{2 i s}(G)$ : method of estimating the sp3 bond content, depending on the $G$ peak dispersion. ${ }^{[26]}$.

Table VII. Nanoindentation Measurement Results of Carbon Coatings Produced on Nitrided Nanobainitic Steel

\begin{tabular}{lcccr}
\hline & \multicolumn{4}{c}{ Parameter } \\
\cline { 2 - 5 } Treatment & Hardness, GPa & Max. Depth, nm & Reduced E, GPa & Plastic Depth \\
\hline NGDCC & $18.01 \pm 5.23$ & $101.90 \pm 13.64$ & $127.96 \pm 36.99$ & $69.59 \pm 10.68$ \\
LTN + RFCVD1 & $15.29 \pm 4.78$ & $101.81 \pm 16.65$ & $144.44 \pm 34.24$ & $76.07 \pm 13.23$ \\
LTN + RFCVD2 & $15.21 \pm 4.93$ & $100.31 \pm 14.23$ & $156.65 \pm 46.59$ & $76.10 \pm 12.19$ \\
\hline
\end{tabular}




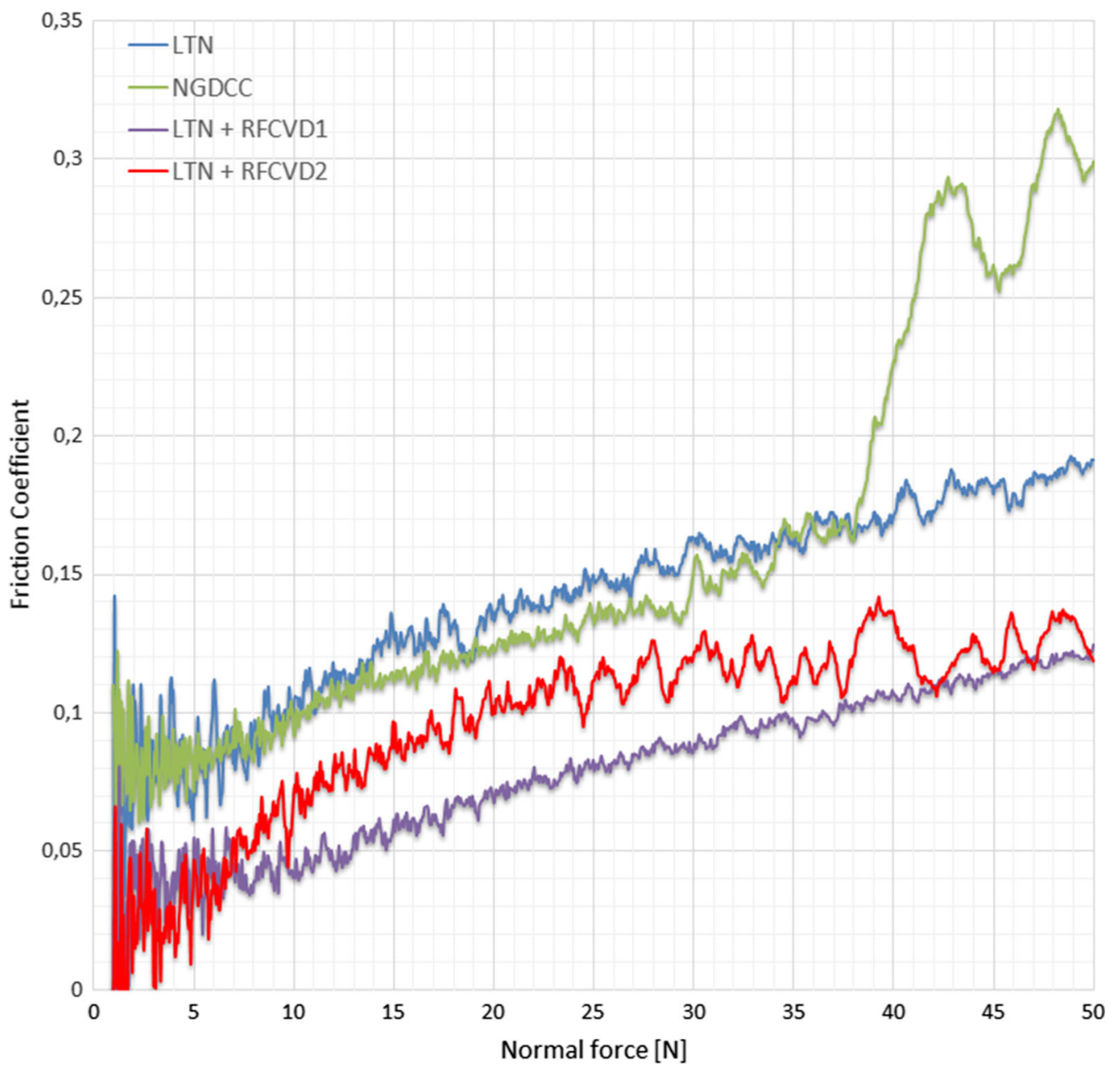

Fig. 9-Friction coefficient of carbon coatings produced on nitrided nanobainitic steel.

stresses in the coating. ${ }^{[4]} \mathrm{A}$ thin compound layer should also improve wear resistance. ${ }^{[45]}$ However, it should be kept in mind that for nanobainitic steels the temperature of nitriding should not exceed some critical value ${ }^{[5]}$ because of the decomposition of nanobainite into ferrite and carbides.

The glow discharge nitriding process is accompanied by a phenomenon called the edge effect - the sputtering which occurs more intensively on the edge of the sample than on the flat surface. As a result, the temperature on the edge is higher and diffusion conditions differ. This phenomenon affects the phase composition, thickness and roughness and hardness of the layer at the edge compared to the flat surface. ${ }^{[46-48]}$ Higher temperature on the edge promotes $\mathrm{Fe}_{4} \mathrm{~N}$ nitride formation ${ }^{[47,49]}$ below the mixture of $\mathrm{Fe}_{2-3} \mathrm{~N}$ and $\mathrm{Fe}_{4} \mathrm{~N}^{[50]}$ As a result of the cathodic sputtering on the edge, some part of a mixture of the nitrides can be removed from the surface ${ }^{[50]}$ Some authors also observed decarburization of the steel at the edge, which ensured formation of $\mathrm{Fe}_{4} \mathrm{~N} \cdot{ }^{[51]} \mathrm{Fe}_{4} \mathrm{~N}$ has higher hardness than an outer zone of a mixture of $\mathrm{Fe}_{4} \mathrm{~N}$ and $\mathrm{Fe}_{2-3} \mathrm{~N}$, ${ }^{[9]}$ Thus, the hardness test $<25$ g gives the hardness of the layer composed of a $\mathrm{Fe}_{4} \mathrm{~N}+\mathrm{Fe}_{2-3} \mathrm{~N}$ mixture. The increase of the load may result in breaking of a thin layer composed of mixtures of nitrides by the indenter and thus higher value of hardness of the inter zone of the $\mathrm{Fe}_{4} \mathrm{~N}$ layer. Therefore, the hardness on the edge may be higher at higher load. The differences in stresses, hardness, roughness and phase composition of the outer zone of the nitride layer at the flat surface and on the edge of the sample may result in differences in adhesion of the coating to the substrate after RFCVD2 process. Ghasemi et al. ${ }^{[40,52]}$ have proved that, among physical, chemical and mechanical factors affecting the adhesion of the coating to the substrate, mechanical bonding is the most important. Decreasing of the surface roughness may adversely affect the adhesion of the coating to the 


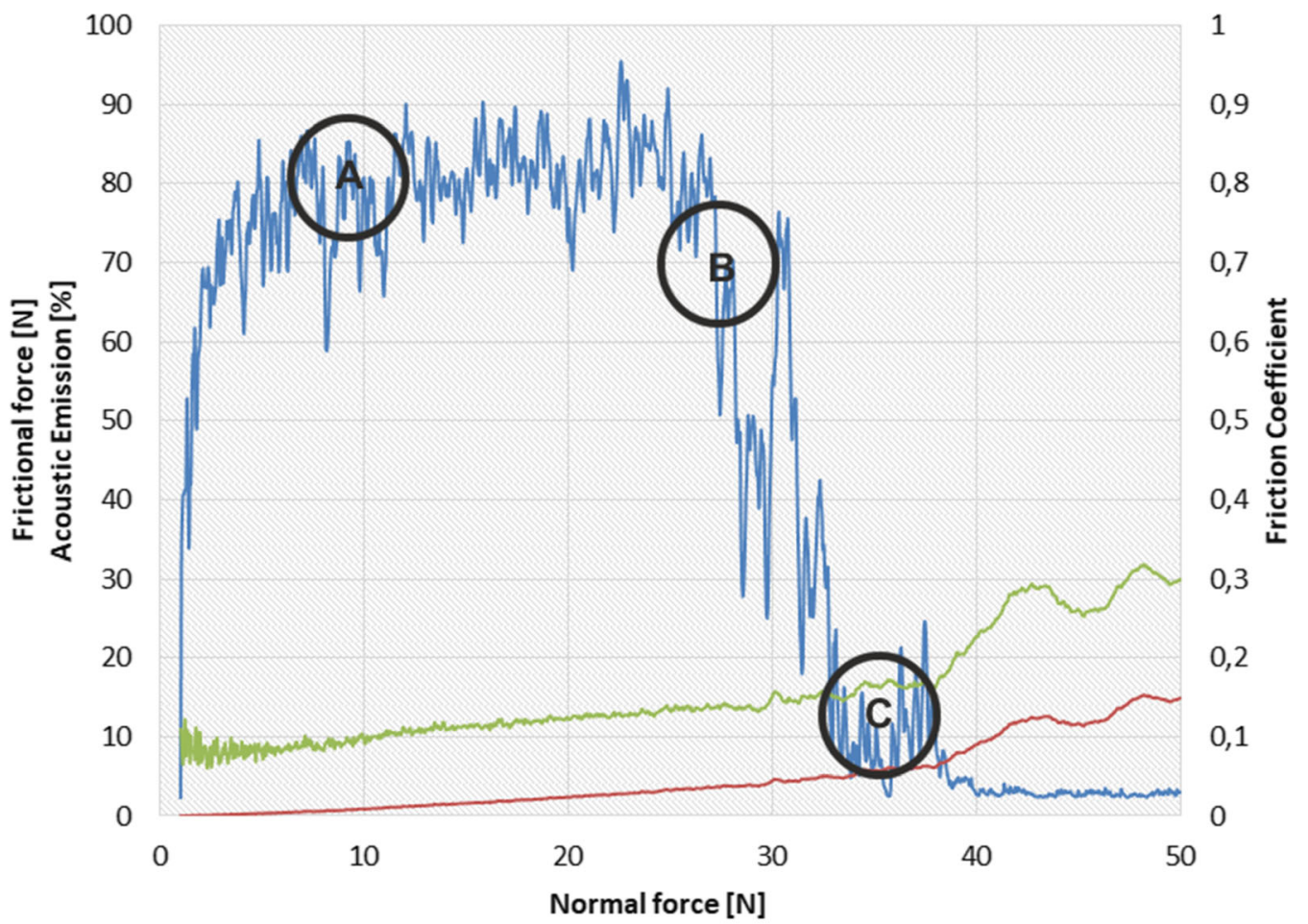

-Acoustic Emission - Frictional force - Friction Coefficient
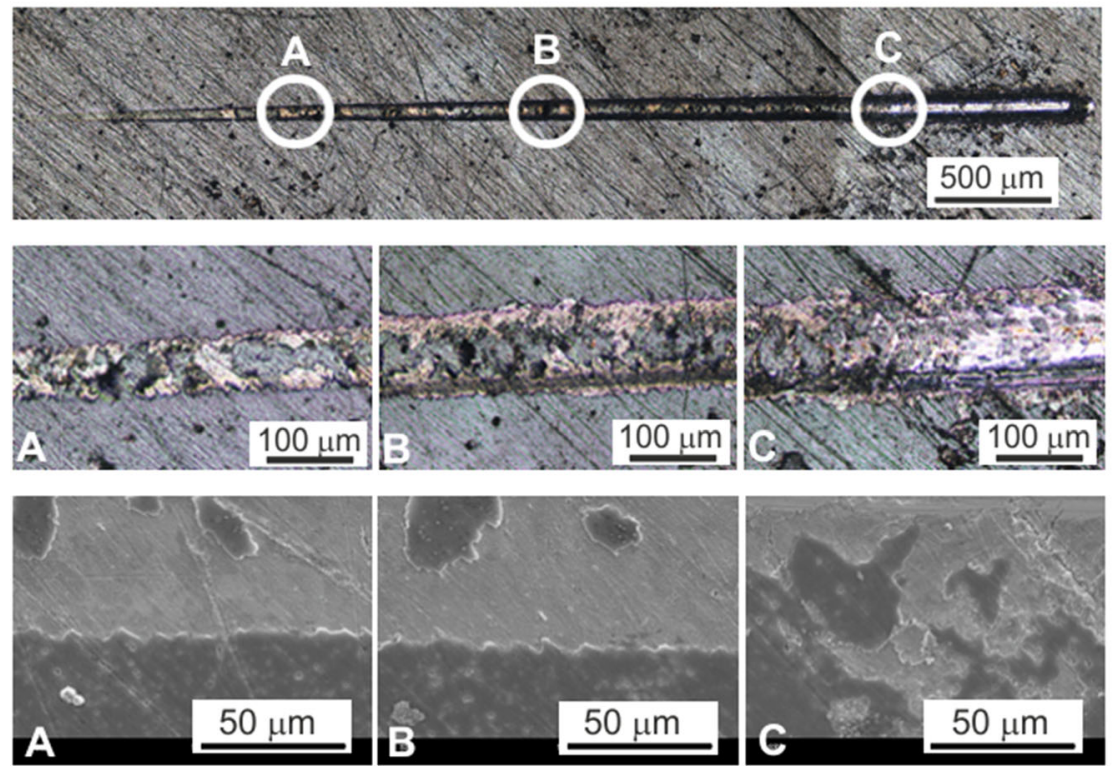

Fig. 10 - Results of scratch test of coating produced on nanobainitic steel by nitriding followed by carbon coating formation in glow discharge conditions (NGDCC). Entire scratch and areas A, B, C.

substrate, which, combined with lower hardness and a thinner zone of nitrides at the edge of investigated sample, may favor coating delamination. Adjusting the process parameters during RFCVD1 could compensate the edge effect and improve the adhesion of the coating to the substrate.
Adhesion and properties of the coating can also be related to the homogeneity of the substrate. ${ }^{[53]}$ Nanobainitic microstructure of investigated steel is quite uniform; however, some areas with blocky austenite with cross sections up to $4.33 \mu \mathrm{m}^{2}$ may appear. ${ }^{[5,24,25]}$ Some of these blocks undergo martensitic 


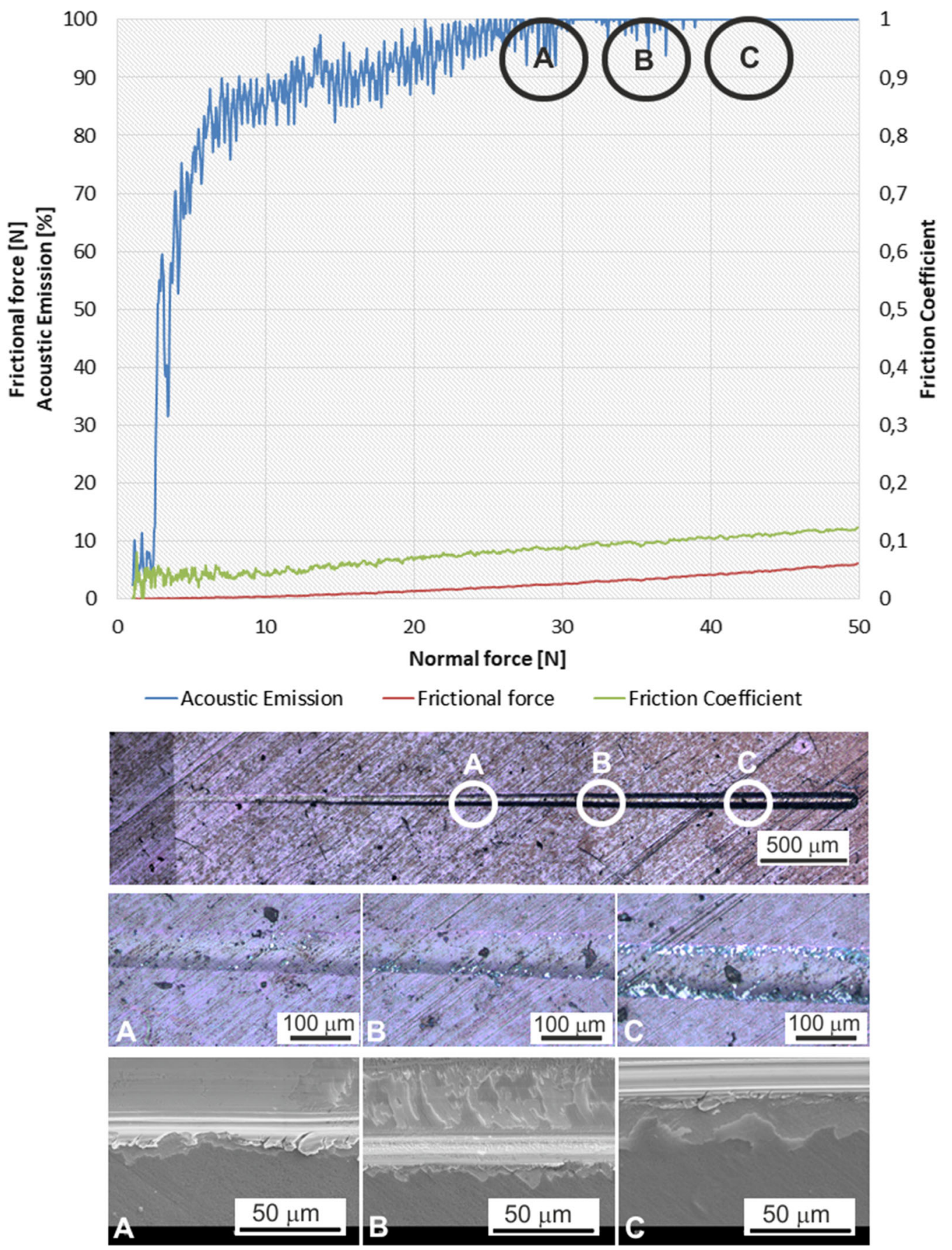

Fig. 11-Results of scratch test of coating produced by RFCVD1 on LTN nanobainitic steel. Entire scratch and areas A, B, C.

transformation; thus, it can be assumed that some variations at the internal stresses at the surface may occur. Some microsegregations of $\mathrm{Mn}$, Mo and carbon near ferrite, residual austenite and martensite interfaces may also appear. ${ }^{[54]}$ These blocky austenite islands, partially transformed into so-called fresh martensite and microsegregations, combined with relatively low hardness of nanobainite, could accelerate and intensify degradation of the coating produced on untreated nanobainitic steel. During nitriding processes, in addition to the diffusion zone, a thin, uniform compound layer probably was formed at the surface, which may 

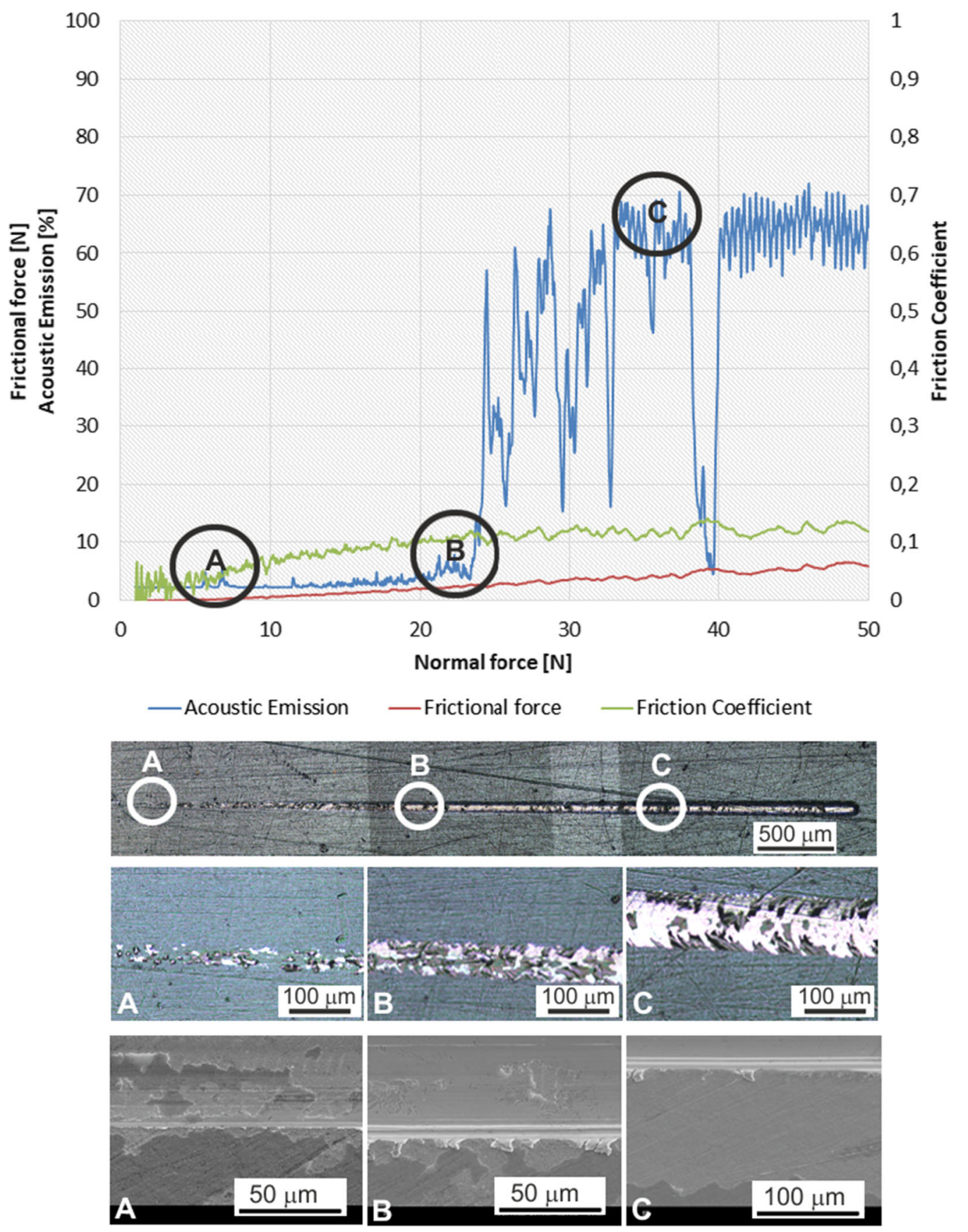

Fig. 12-Results of scratch test of coating produced by RFCVD2 on LTN nanobainitic steel. Entire scratch and areas A, B, C.

have eliminated the influence of blocky austenite with fresh martensite islands and local chemical composition differences on the adhesion of thin carbon coatings.

\section{CONCLUSIONS}

A low-temperature process such as glow discharge carbon coating production or a RFCVD allows producing thin carbon films on the surface of nanobainitic steel.
The carbon coatings cannot be directly deposited on a surface of nanobainitic steel because the adhesion between coating and nanobainitic substrate is very low. It was shown that the hard intermediate layer obtained by low-temperature glow discharge nitriding process was necessary to ensure high adhesion of the carbon coating to the substrate.

The produced carbon coatings obtained through the NGDCC process display hardness as high as in DLC layers. However, due to insufficient amorphization, the obtained layer cannot be defined structurally as a DLC layer, but rather as a hard carbon coating. 
Hard carbon thin films show much higher hardness and lower friction coefficients than nanobainitic steel or nanobainitic steel subjected to glow discharge nitriding.

\section{ACKNOWLEDGMENTS}

The experimental research was carried out as a part of the project "Development of an innovative technology for the manufacture of toothed components with hybrid surface layers with a nanostructure base for the drive units of conveyors designed to be used in extreme operating conditions," No. POIR.04.01.04-00-0064/15.

\section{OPEN ACCESS}

This article is licensed under a Creative Commons Attribution 4.0 International License, which permits use, sharing, adaptation, distribution and reproduction in any medium or format, as long as you give appropriate credit to the original author(s) and the source, provide a link to the Creative Commons licence, and indicate if changes were made. The images or other third party material in this article are included in the article's Creative Commons licence, unless indicated otherwise in a credit line to the material. If material is not included in the article's Creative Commons licence and your intended use is not permitted by statutory regulation or exceeds the permitted use, you will need to obtain permission directly from the copyright holder. To view a copy of this licence, visit http://creat ivecommons.org/licenses/by/4.0/.

\section{REFERENCES}

1. F.G. Caballero, H.K.D.H. Bhadeshia, and K.J.A. Mawella: Mater. Sci. Technol., 2002, vol. 18, pp. 279-284, https://doi.org/ 10.1179/026708301225000725.

2. C. Garcia-Mateo, F.G. Caballero, and H.K.D.H. Bhadeshia: ISIJ Int., 2003, vol. 43, pp. 1821-1825, https://doi.org/10.2355/ isijinternational.43.1821.

3. C. Garcia-Mateo, F.G. Caballero, and H.K.D.H. Bhadeshia: ISIJ Int., 2003, vol. 43, pp. 1238-1243, https://doi.org/10.2355/ isijinternational.43.1238.

4. E. Jezierska, J. Dworecka, and K. Rożniatowski: Achiev. Metall. Mater., 2014, vol. 59, pp. 1633-1636, https://doi.org/10.2478/ amm-2014-0277.

5. E. Skołek, S. Marciniak, and W. Świątnicki: Achiev. Metall. Mater., 2015, vol. 60, pp. 511-516, https://doi.org/10.1515/amm2015-0082.

6. A.R. Olszyna: Superhard ceramics (in polish), Oficyna Wydawnicza Politechniki Warszawskiej,

7. H. Ronkainen, S. Varjus, J. Koskinen, and K. Holmberg: Wear, 2001, vol. 249, pp. 260-266, https://doi.org/10.1016/S00431648(01)00558-0.

8. J. Robertson: Mater. Sci. Eng., 2002, vol. 37, pp. 129-281, https:// doi.org/10.1016/S0927-796X(02)00005-0.

9. V.M. Puzikov and A.V. Semenov: Surf. Coat. Technol., 1991, vol. 47, pp. 445-454, https://doi.org/10.1016/0257-8972(91)90310S.
10. X.-M. He, W.-Z. Li, and H.-D. Li: Surf. Coat. Technol., 1996, vol. $\quad 84$, pp. 414-419, https://doi.org/10.1016/S02578972(95)02818-8.

11. V. Anita, T. Butsuda, N. Saito, and O. Takai: Vacuum, 2006, vol. $\quad 80, \quad$ pp. 736-739, https://doi.org/10.1016/ j.vacuum.2005.11.020

12. A. Modabberasl, P. Kameli, M. Ranjbar, H. Salamati, and R. Ashiri: Carbon, 2015, vol. 94, pp. 485-493, https://doi.org/ 10.1016/j.carbon.2015.06.081.

13. M. Tarnowski et al.: Diam. Relat. Mater., 2017, vol. 75, pp. 123-130, https://doi.org/10.1016/j.diamond.2017.02.013.

14. T. Stapiński, Uczelniane Wydawnictwa Naukowo-Dydaktyczne, Kraków 2008

15. CA. Charitidis: J. Refract. Metals Hard Mater., 2010, vol. 28, pp. 51-70, https://doi.org/10.1016/j.ijrmhm.2009.08.003.

16. T. Borowski et al.: Surf. Coat. Technol., 2020, vol. 392, art. no. 125705https://doi.org/10.1016/j.surfcoat.2020.125705.

17. T. Borowski et al.: Arch. Metall. Mater., 2020, vol. 65 (3), pp. 1141-1146, https://doi.org/10.24425/amm.2020.133231.

18. T. Borowski et al.: Mater. Sci., 2016, vol. 22 (3), pp. 323-329, https://doi.org/10.5755/j01.ms.22.3.7532.

19. M.H. Ghasemi et al.: Diam. Relat. Mater., 2019, vol. 93, pp. 8-15, https://doi.org/10.1016/j.diamond.2019.01.016.

20. P. Zhang, F.C. Zhang, Z.G. Yan, T.S. Wang, and L.H. Qian: Wear, 2011, vol. 271, pp. 697-704, https://doi.org/10.1016/ j.wear.2010.12.025.

21. F.C. Zhang, T.S. Wang, P. Zhang, C.L. Zheng, B. Lv, M. Zhang, and Y.Z. Zheng: Scripta Mater., 2008, vol. 59, pp. 294-296, https://doi.org/10.1016/j.scriptamat.2008.03.024.

22. P. Zhang, F.C. Zhang, and T.S. Wang: Appl. Surf. Sci., 2011, vol. 257, pp. 7609-7614, https://doi.org/10.1016/ j.apsusc.2011.03.138.

23. D. Fabijanic, I. Timokhina, H. Beladi, and P. Hodgson: Metals, 2017, vol. 7, pp. 1-8, https://doi.org/10.3390/met7070234.

24. E. Skołek, S. Marciniak, P. Skoczylas, J. Kaminski, and W.A. Swiatnicki: Achiev. Metall. Mater., 2015, vol. 60, pp. 491-493, https://doi.org/10.1515/amm-2015-0079.

25. E. Skołek, S. Marciniak, and W. Świątnicki: Achiev. Metall. Mater., 2015, vol. 60, pp. 517-521, https://doi.org/10.1515/amm2015-0083.

26. W.G. Cui, Q.B. Lai, L. Zhang, and F.M. Wang: Surf. Coat. Technol., 2010, vol. 205, pp. 1995-1999, https://doi.org/10.1016/ j.surfcoat.2010.08.093.

27. A.C. Ferrari, A. Libassi, B.K. Tanner, V. Stolojan, J. Yuan, L.M. Brown, S.E. Rodil, B. Kleinsorge, and J. Robertson: Phys. Rev. B, 2000, vol. 62, pp. 11089-11103, https://doi.org/10.1103/ PhysRevB.62.11089.

28. A.C. Ferrari: Diam. Relat. Mater., 2002, vol. 11, pp. 1053-1061, https://doi.org/10.1016/S0925-9635(01)00730-0.

29. PN-EN ISO 6507-1:2018-05, Metallic materials-Vickers hardness test-Part 1: Test method.

30. ASTM C1624-05, Standard Test Method for Adhesion Strength and Mechanical Failure Modes of Ceramic Coatings by Quantitative Single Point Scratch Testing.

31. K. Zdunek, R. Chodun, B. Wicher, K. Nowakowska-Langier, and S. Okrasa: Spectrochim. Acta Part A, 2018, vol. 194, pp. 136-140, https://doi.org/10.1016/j.saa.2018.01.015.

32. C. Casiraghi, A.C. Ferrari, and J. Robertson: Phys. Rev. B, 2005, vol. 72, art. no. $085401 \mathrm{https} / / /$ doi.org/10.1103/ PhysRevB.72.085401.

33. A.C. Ferrari and J. Robertson: Phys. Rev B, 2000, vol. 61, pp. 14095-14107, https://doi.org/10.1103/PhysRevB.61.14095.

34. B. Ben-Nissan, A.H. Choi, B.A. Latella, and A. Bendavid: Comprehensive Biomater. II, 2017, vol. 3, pp. 128-143, https://doi.org/ 10.1016/B978-0-12-803581-8.10102-X.

35. Z. Zhang and J. Luo: Encyclopedia of Tribology, Springer, Boston, 2013.

36. H. Kovaci, Ö. Baran, A.F. Yetim, Y.B. Bozkurt, L. Kara, and A. Çelik: Surf. Coat. Technol., 2018, vol. 349, pp. 969-979, https:// doi.org/10.1016/j.surfcoat.2018.05.084.

37. A. Erdemir: Tribol. Int., 2004, vol. 37, pp. 1005-1012, https:// doi.org/10.1016/j.triboint.2004.07.018.

38. K.R. Lee, K.Y. Eun, I. Kim, and J. Kim: Thin Solid Films, 2000, vols. $377-378$, pp. $261-268$. 
39. R. Ali, M. Sebastiani, and E. Bemporad: Mater. Des., 2015, vol. 75, pp. 47-56, https://doi.org/10.1016/j.matdes.2015.03.007.

40. M.H. Ghasemi, B. Ghasemi, and H.R.M. Semnani: Diamond Relat. Mater., 2019, vol. 93, pp. 8-15, https://doi.org/10.1016/ j.diamond.2019.01.016.

41. A. da Silva Rocha, T. Strohaecker, V. Tomala, and T. Hirsch: Surf. Coat. Technol., 1999, vol. 115, pp. 24-31, https://doi.org/ 10.1016/S0257-8972(99)00063-8.

42. H. Kovacı, Ö. Baran, Ö. Bayrak, A.F. Yetim, and A. Celik: J. Adhes. Sci. Technol., 2017, vol. 31, pp. 2015-2027, https://doi.org/ 10.1080/01694243.2017.1293923.

43. C. Alves, Jr, E.F. Silva, and A.E. Martinelli: Surf. Coat. Technol., 2001, vol. 139, pp. 1-5, https://doi.org/10.1016/S02578972(00)01146-4.

44. B. Podgornik, J. Vizintin, H. Ronkainen, and K. Holmberg: Thin Solid Films, 2000, vols. 377-378, pp. 254-260, https://doi.org/ 10.1016/S0040-6090(00)01302-X.

45. B. Podgornik and J. Vižintin: Influence of substrate treatment on the tribological properties of DLC coatingsDiam. Relat. Mater., 2001, vol. 10, pp. 2232-2237, https://doi.org/10.1016/S09259635(01)00514-3.

46. V. Leskovšek, B. Podgornik, and D. Nolan: Mater. Charact., 2008, vol. 59, pp. 454-461, https://doi.org/10.1016/ j.matchar.2007.03.009.
47. R.R.M. de Sousa, Y.J.L. Moura, P.A.O. de Sousa, J.Q.M. Neto, T.H. de Carvalhocosta, and C. Alves, Jr.: Mat. Res., 2014, https:// doi.org/10.1590/S1516-14392014005000027.

48. M. Olzon-Dionysio, M. Campos, M. Kapp, S. de Souza, and SD. de Souza: Surf. Coat. Technol., 2010, vol. 204, pp. 3623-3628, https://doi.org/10.1016/j.surfcoat.2010.04.034.

49. T. Burakowski and T. Wierzchon: Surface Engineering of Metals (in polish), Wydawnictwo Naukowo-Techniczne, Warszawa, 1995.

50. T. Borowski, J. Kamiński, J. Trojanowski, and T. Wierzchoń: Archiwum Technologii Maszyn i Automatyzacji, 2010, vol. 30, pp. 69-77.

51. C. Ruset, S. Ciuca, and E. Grigore: Surf. Coat. Technol., 2003, vols. 174-175, pp. 1201-1205, https://doi.org/10.1016/S02578972(03)00589-9.

52. M.H. Ghasemi, B. Ghasemi, H.R.M. Semnani, and M. Erfanmanesh: Ceram. Int., 2021, vol. 47, pp. 12467-12475, https:// doi.org/10.1016/j.ceramint.2021.01.104.

53. H. Shafyei and R. Ashiri: Ceram. Int., 2019, vol. 45, pp. 14821-14828, https://doi.org/10.1016/j.ceramint.2019.04.213.

54. I.B. Timokhina, M.K. Miller, H. Beladi, and P.D. Hodgson: J. Mater. Res., 2016, vol. 31, pp. 806-818, https://doi.org/10.1557/ jmr.2016.73.

Publisher's Note Springer Nature remains neutral with regard to jurisdictional claims in published maps and institutional affiliations. 